\title{
Native and Popular Elements in Latin American Design as a Strategy for Diversity as Opposed to the Globalization of Cultural Forms
}

Renata Ribeiro Dos Santos* Ana María Fernández García University of Oviedo, Spain

\begin{abstract}
:
The paper constructs a critical reflection on how the decolonial postulates and critique of coloniality, elaborated in Latin America, point to the strategy of pluralization and multiplicity of forms in the face of the homogenization imposed by the modernity/globalization binomial. Based on these assumptions, some examples are outlined of designers who, since the 1950 s and in the Latin American sphere, have incorporated native and popular elements in their creations as a response to the standardization of consumption derived from globalization and the stylistic canon born of the modern movement and accentuated in post-modernity.
\end{abstract}

Keywords: globalization, modernity, decolonial, design, Latin America.

\section{Globalization and Modernity vs Heterogeneity}

In recent years, the term globalization has reached colloquial language, being incorporated into the most trivial of conversations. A concept previously linked to economic factors - related to the use of transnational capital through a network of international business relations which have created asymmetric connections and dependency among countries - has reached the present, being understood as a multi-dimensional process, a determining factor in the configuration of the political, cultural and social landscape. 
Defining and delimiting globalization is a task in which scholars from different areas have been heavily involved in recent years: 'globalization is not a clearly defined object of study, nor is it a scientific paradigm, nor economic, nor political nor cultural that can be hypothesized as the only model for development'. ${ }^{1}$ This perception - as a multi-focussed process- is in accordance with the proposal that globalization is intrinsic to the historical project of modernity. ${ }^{2}$ In this case, it may be affirmed that globalization is beginning to take shape, together with western territorial expansion in the Renaissance, and will impose, in the most diverse corners of the globe, its economic models and hegemonic norms of social, cultural and institutional functioning, 'considered ethnocentrically as a paradigm for the culmination of progress and human civilization'. ${ }^{3}$ This Western reasoning has been applied by justifying itself in a constant search for progress, a progress which supported an ideal which was gradually imposed on non-western peoples. In this way, a perverse logic was founded between 'the philosophical dilemma of modernity/colonialism and the political and economic structure of imperialism/colonialism'. ${ }^{4}$

Meanwhile, other authors situate the beginnings of globalization in the second half of the $20^{\text {th }}$ century. ${ }^{5}$ Contrary to those who situate globalization in previous dates, which favour the economic motor of the process, the defence of the design of globalization in more recent times highlights those characteristics related to cultural, political and communicational configuration, subsumed in the process. However, it is important to point out that the defence of globalization as a phenomenon from the middle of the $20^{\text {th }}$ century understands that the changes and transformations which occurred from the $15^{\text {th }}$ century onwards, at the beginning of capitalism and modernity, should be considered as direct precedents which lay the ground for the arrival of the global era. ${ }^{6}$

In the $21^{\text {st }}$ century, with the concept of globalization having been widely accepted and incorporated into different levels of the social structure, research and reflections suggest 'global tendencies of homogenization and loss of identity', 
which begins to be a majority opinion in the shaping of cultural spaces and products. The heterogeneity of other cultural forms - other non-western cultures and minorities within western societies - became largely blurred, ignoring and destroying local and indigenous knowledge, or, what is usually referred to as tradition.

And so, what is tradition? It was the thought from the Enlightenment in the $18^{\text {th }}$ century that constructed the generic notion of tradition which is used today and which was weighed down with prejudices. 'On identifying tradition with dogma and ignorance, thinkers from the Enlightenment sought to justify their obsession with everything new'. ${ }^{8}$ However, how can we return to tradition by negotiating diverse degenerative obstacles that impregnated modern developmentalism? One of the theses which Anthony Giddens considers with regard to this issue is that it must be understood that, in their totality, traditions are (or were) invented: 'It is a myth to think that traditions are impermeable to change: they develop over time, but, they can also be suddenly altered or transformed. I would say that they are invented and reinvented'. ${ }^{9}$

However, tradition did not disappear despite the intentions of the Enlightenment, but rather, it could be said that it survived, it reinvented itself and was reconstructed in modern central societies but mainly in peripherical areas. The undertaking of blurring traditions will finally be part of the task of globalization, where both institutions as well as everyday life began to distance themselves or break away from the influences of tradition. This factor is what Giddens defines as 'the emerging global society'. ${ }^{10}$

Contrary to the homogenization of forms and cultural products and the dissipation of traditions, a series of voices arose from different areas of thought that put forward an intellectual line of intermediate action: between homogenizing developmentalism motivated by modernity/globalization and the imitative return to the past and the traditions of post-modernism. This attitude was assumed and developed by post-colonial discourse - arising from 
theorists from Central Asia - that would be reflected in Latin America, being contaminated by post-colonial postulates but drawing on sources, concepts and theories that were transferred to local specificities in their historical and local construction. As precursors and defenders of this pluralizing thought in Latin America, the concept of Nuestra América (Our America) by José Martí11, the pro-Indian discourse of José Carlos Mariátegui ${ }^{12}$, transculturation as proposed by the Cuban anthropologist Fernand Ortiz ${ }^{13}$, the negritude of the poet and politician Aimé Césaire ${ }^{14}$, the questions surrounding decolonization proposed by Frantz Fanon ${ }^{15}$ and, more recently, cultural hybridisation as pointed out by Néstor García Canclini. ${ }^{16}$ Later, building on theoretical roots mixed with contributions from post-colonial theory, Latin American thought established the so-called decolonial option, developed largely in the heart of the Grupo Modernidad/Colonialidad (Modernism/Colonialism Group). ${ }^{17}$

One of the great flags of decolonial thought will be the enhancement of local knowledge in contrast to the intrinsic homogenisation of modernity, expanded in the process of colonisation. To explain how colonisation impregnates, defines and overwhelms different areas of a suppressed social structure, the concept of colonialism has been developed. This concept is different from colonization, this being a process and an enterprise which can be given a starting date and ending, with a rupture, in decolonization. Meanwhile, colonialism is the feeling or the mark left by colonisation on social systems. Therefore, it extends to different spheres, forming what is known as colonialism of being, of knowledge and of power. The overcoming of colonialism can be carried out through a decolonial strategy, an epistemological decolonisation than overruns, disobeys and breaks from all aspects contained in colonisation and colonialism. ${ }^{18}$

So, how can the episteme imposed by colonial processes and later by globalisation be broken? How can homogenization be negotiated and how can knowledge, points of view and cultural production be pluralised?

Early on, in 1999, the Argentinian anthropologist based in Mexico, Néstor 
García Canclini, contemplated the necessity of 'rethinking how to produce art, culture and communication'19 in the era of globalisation which was being experienced, making it a central hypothesis of his book: La globalización imaginada (Imagined Globalisation). In this work ${ }^{20}$ he sustains that, different to previous moments when the producers of culture (scientists and artists) negotiated their points of view, their ways of doing and understanding with identifiable, key figures (patrons, politicians, institutions), now this landscape becomes more complex since it is obligatory to negotiate with a power which is not personified: globalisation. Likewise, at the heart of the decolonial option, the concepts of epistemic disobedience and decolonial aesthesis were used, strategies used to breach rules and hegemonic impositions enforced from the womb of the colonial power. This decolonial thought understands that these strategies were formulated from the beginning of the process of colonisation. Such manoeuvres have been used by suppressed populations to conserve and maintain local knowledge: resisting, disobeying and transgressing, initially, the norms of modernity later transferred to globalization.

What is understood by epistemic disobedience ${ }^{21}$ is that the capacity for shattering, for breaking with western epistemic norms, constitutes a tool for the decolonisation of knowledge and of beings. ${ }^{22}$ While, to understand decolonial aesthesis it is necessary to return to the transition of the broad concept of aesthesis (sensation, production of perception) towards its reduction to "sensation of what is beautiful' or beauty imposed by aesthetic theory developed from the $17^{\text {th }}$ century onwards. What in principle is not a problem can become complex when this concept of beauty, developed in modern Europe, is not able to be universalised, transforming itself into a model that should be imitated by all non-western cultures. In this way, as a form of resistance to this hegemonic imposition, the option of decolonial aesthesis is proposed. ${ }^{23}$

The decolonial option can be seen, therefore, as a means of negotiation with the invisible power of globalisation and a strategy to ensure the permanence 
and heterogeneity of cultural forms. This strategy was present in Latin America from the very moment of conquest and can be seen reflected in the resistance of certain cultural products or in the detachment ${ }^{24}$ of norms established by central powers. The quintessential example of this are the writings of Guamán Poma de Ayala, La Nueva Crónica y Buen Gobierno (The First New Chronical and Good Government), 'an introduction to a new form of recounting history. It is, effectively, an epistemic break in the writing of history'. ${ }^{25}$

The following section will analyse how, in the current design of furniture and objects in Latin America, the persistence or the inclusion of elements imbued with local and indigenous knowledge are used as a strategy for diversity and detachment in the face of the normative homogenization of globalization.

\section{Latin American design as an allegation against globalisation}

The origin of industrial design in all of Latin America is linked to the arrival of ideas from European rationalism, with the sojourn of Le Corbusier in Brazil and Argentina in 1929 or that of Josef Albers in Cuba, Chile and Peru, as well as with the arrival of European creators. The continent was progressively included in the process of globalization under the wide conceptual and formal umbrella of the Modern Movement. ${ }^{26}$ The early signs of a response to European and North American rationalism in Brazil were related, strangely enough, to designers born in the old continent, like Joaquim Tenreiro or Lina Bo Bardi.

The Portuguese designer, Joaquim Tenreiro, has been considered the father of modern Brazilian design ${ }^{27}$ because, even though he was really a sculptor who made furniture, he was also the first to reject mere copies of European models and to become involved in the wood carving of the indigenous people and in the use of indigenous species. One of his more well-known works was the Três Pes Armchair (Fig.1) with a structure of a number of different encrusted woods without nails. It has a soft, prolonged curve in its back in a design which simplifies colonial stools. Tenreiro's design combines knowledge of 
local materials with ergonomic concerns, and also knowledge of the techniques of cabinetmaking, while taking into account the pieces which function best in the context of Brazil. ${ }^{28}$ It is considered to be one of the masterworks of design in Brazil precisely because, in its simplicity, it adheres to the indigenous benches of the Tukan tribes, slightly curved and, of course, in the relaxed position of hammocks. ${ }^{29}$

As an architect, the Brazilian-Italian Lina Bardi wished to harmonize construction with the magnificence of Brazil's natural environment, achieving the balance of each building with the environment. In the area of design, she opted for respect for materials and for the traditional use of furniture in her

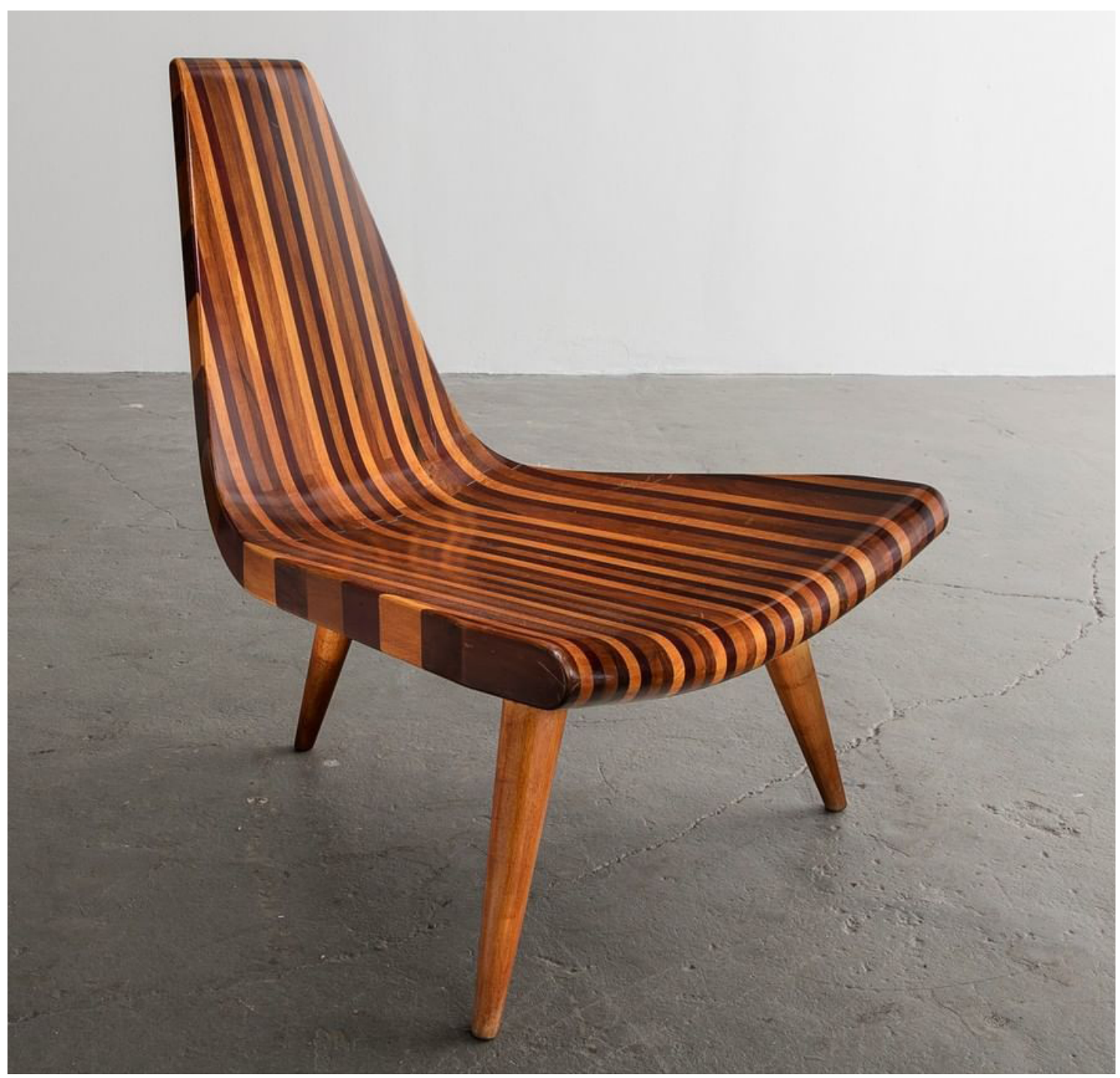

Fig. 1: Joaquim Tenreiro. Poltrona Três Pés (Três Pes Armchair) @ R\&Company https://www.r-and-company.com/tenreiros-cadeira-de-tres-pes/ 
adopted country. A good example of this integration of modern language, in which she had been trained in Italy by Giò Ponti, and vernacular Brazilian customs is the Tripé Armchair (Fig. 2), created in the Studio d'Arte Palma in 1948, which she founded together with Giancarlo Pallanti. An anthropological study of ways of sitting and sleeping of indigenous South Americans, both in inhabited areas of the Amazon as well as the 'gaiola' boats which travelled the great rivers of the north of the country, underlies this design. In both contexts rudimentary string nets or hammocks were used. These were defined by the architect as perfect elements for repose because the body was suspended without tensions. ${ }^{30}$ The structure, whether in metal or wood, with three supporting elements, allows the chair to be in a reclining position or suspended, as in popular Brazilian models. In 1967 Lina presented her Cadeira de beira de Estrada (roadside chair) (Fig.3 and 4), which can be interpreted as a manifestation of her implication in popular culture, specifically the African legacy in Brazil. The collection of the Instituto Lina Bo Bardi and P. M. Bardi contains a photograph of two children from an unidentified African tribe who are resting on some very basic bamboo structures tied in the form of a pyramid and which, so it seems, were also used as chairs in the remote area of Mato Grosso. This chair is a simplification of a basic and versatile body support in cultures with little technological sophistication. However, in Bo Bardi's hands, it is converted into a return, not only to the moment before the industrialization of processes, as happened with the Tripe Armchair with its reference to the hammocks of textile crafts, but rather to objects previous to crafts, with improvised materials taken from the immediate environment, poor and yet efficient. ${ }^{31}$

Since the forefathers Tenreiro and Bo Bardi, Brazilian design has passed through all international tendencies although it is possible to find proposals of decolonial redefinition. An example would be the work of Brunno Jahara whose design "has specific Brazilian features, in which the outcome is a familiar and original language". ${ }^{32}$ In this sense, some of his collections like Palafita 


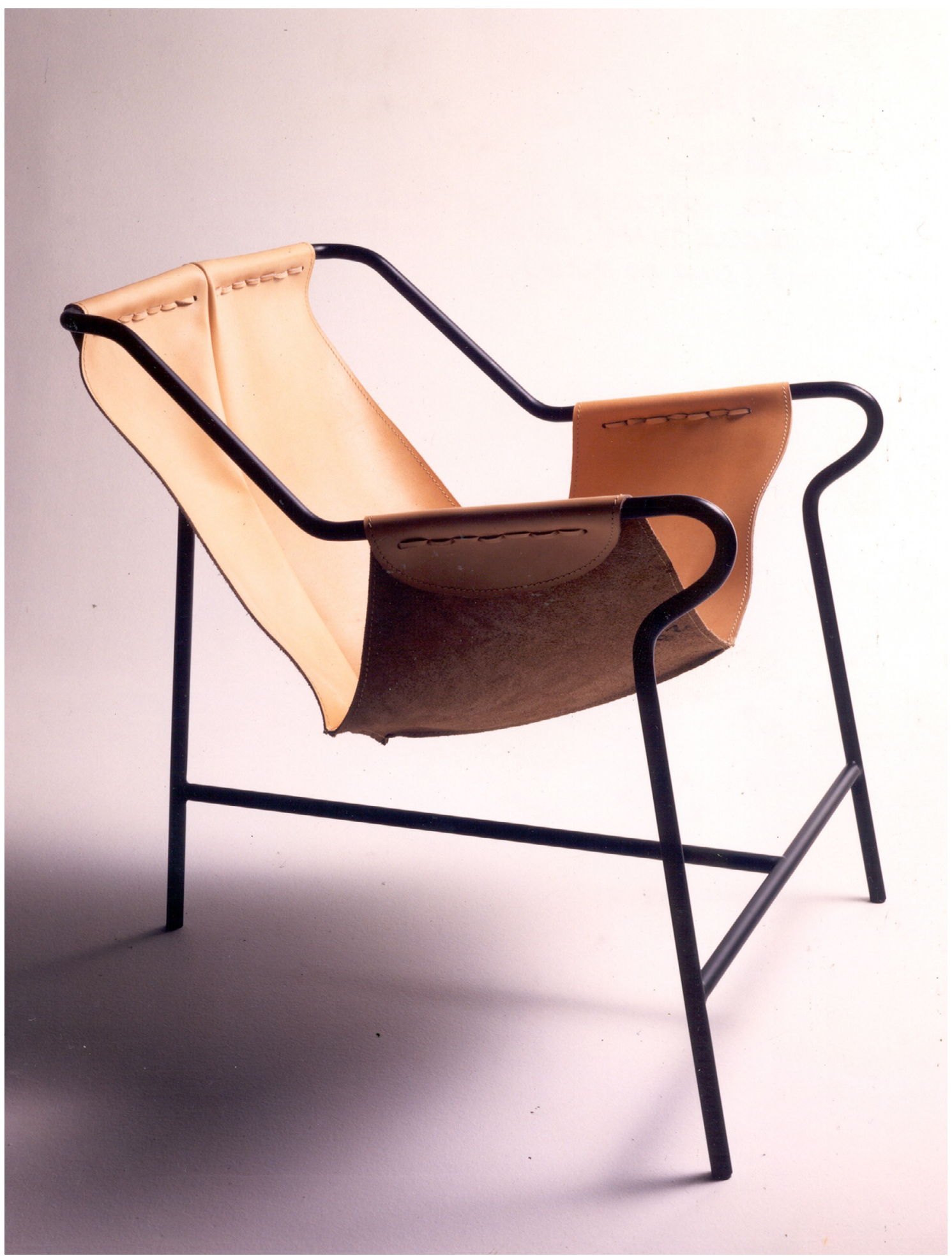

Fig. 2: Cadeira Tripé (Tripé Armchair) designed by Lina Bo Bardi, undated. Unknown photographer. CInstituto Bardi / Casa de Vidro 


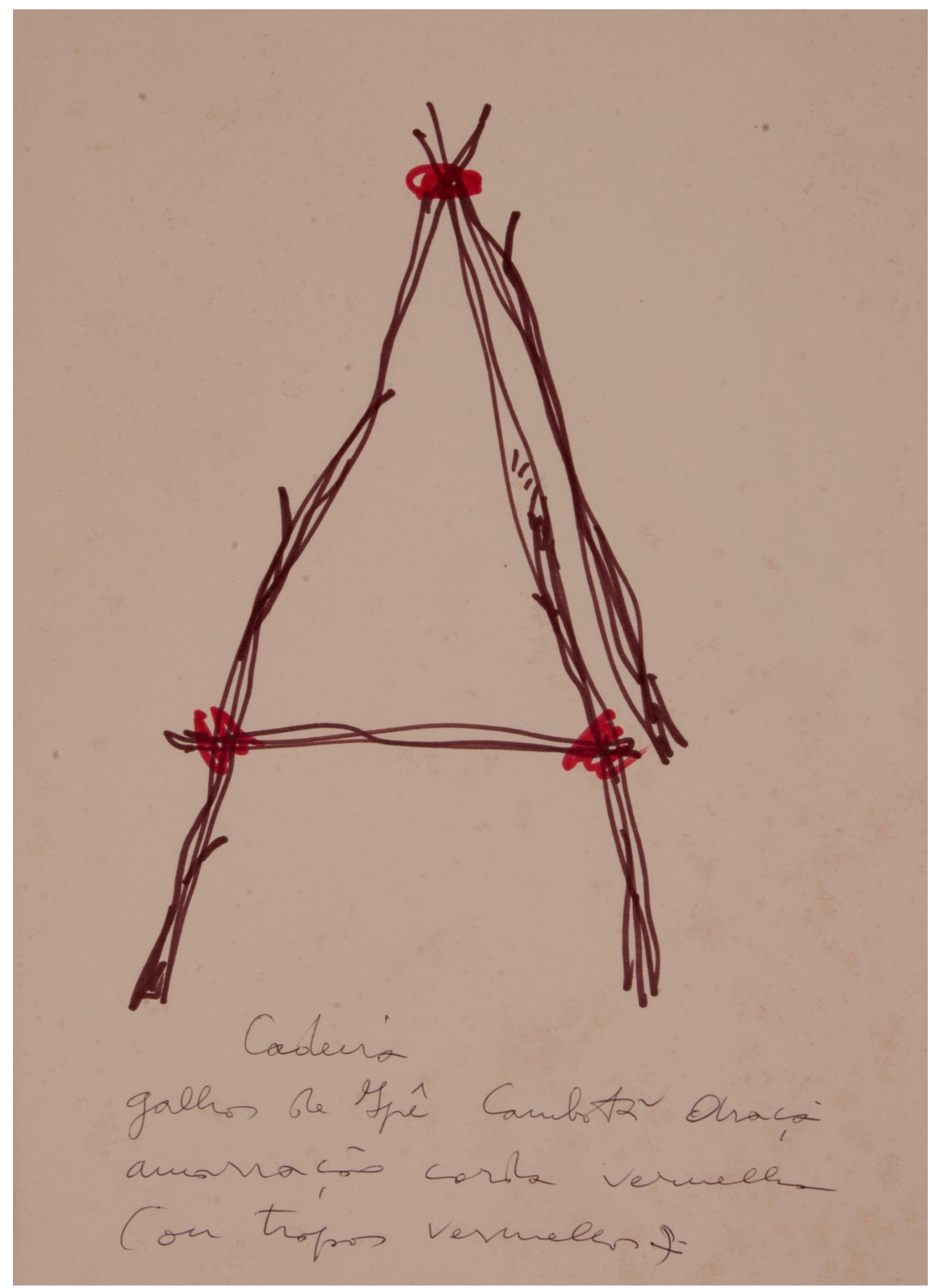

Fig. 3: Lina Bo bardi. Cadeira de beira de Estrada (Roadside Chair) Study, c. 1967 ( ) Instituto Bardi / Casa de Vidro 


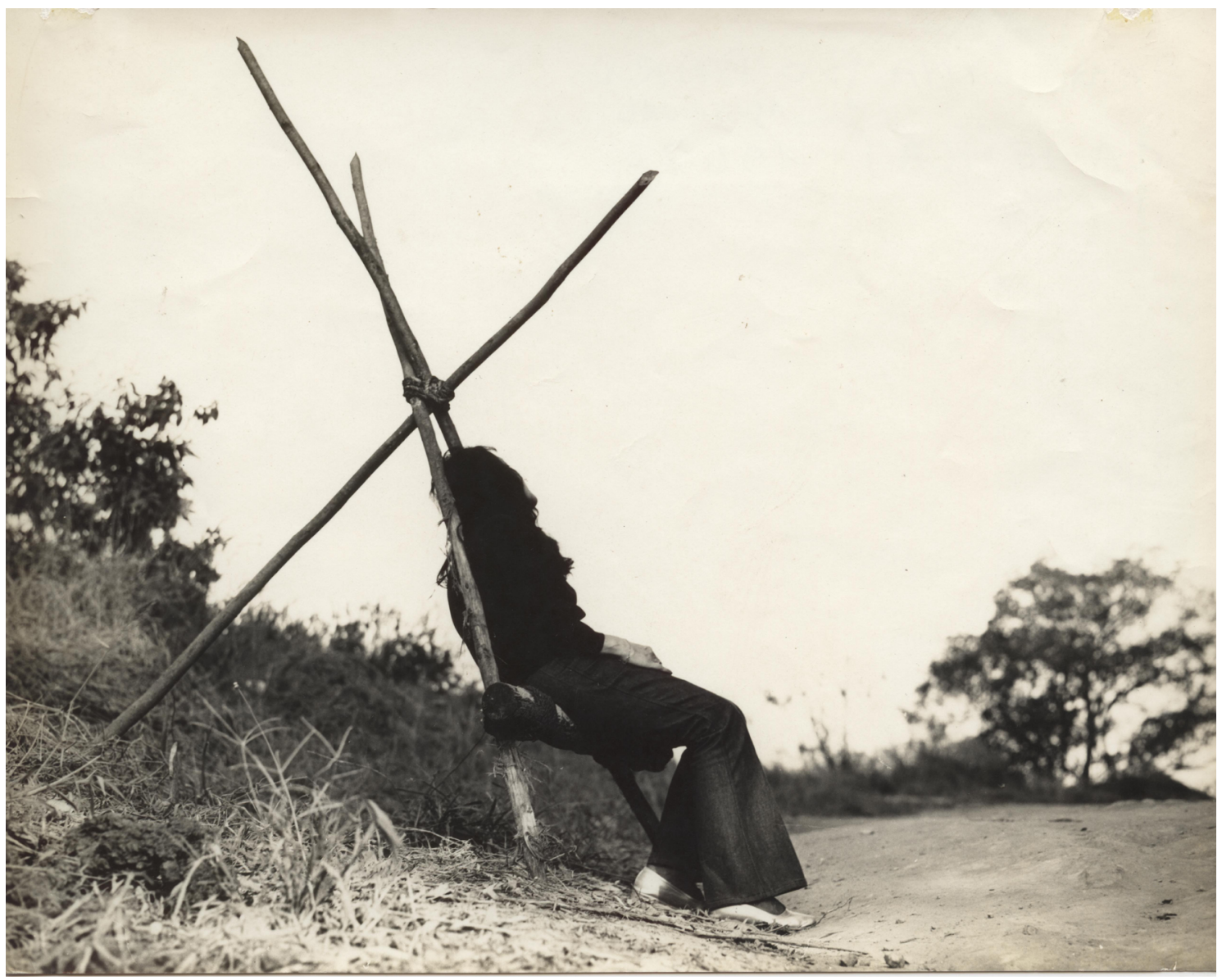

Fig. 4: Lina Bo bardi. Cadeira de beira de Estrada (Roadside Chair) Study, c. 1967.

Unknown photographer (C Instituto Bardi / Casa de Vidro

(Fig.5) and Nova Palafita (2014) stand out. These were inspired by the elevated constructions from the north of the country to ease the effects of floods. Also, there are the nine objects of Paleae Brasilis, conceived by the fashion designer Ana Voss, who reinterprets the clothing and popular recipients made of straw, applying these to lamps, fruit baskets or hats. In addition, the brothers Fernando and Humberto Campana (Campana Studio) show a special sensitivity to their culture of origin, with the example of the inexpensive materials used in the Favela chair (1991), by falling back on the technical tradition of wood and straw crafts in Dois Irmãos (Two Brothers) (Fig.6) or even with the inspiration of the Amazon vegetation as occurs in the Naiá lamp for Artemide.

The creativity of new Brazilian design, so rich in emotional qualities and with enormous potential for employment for the large workforce of the country, 


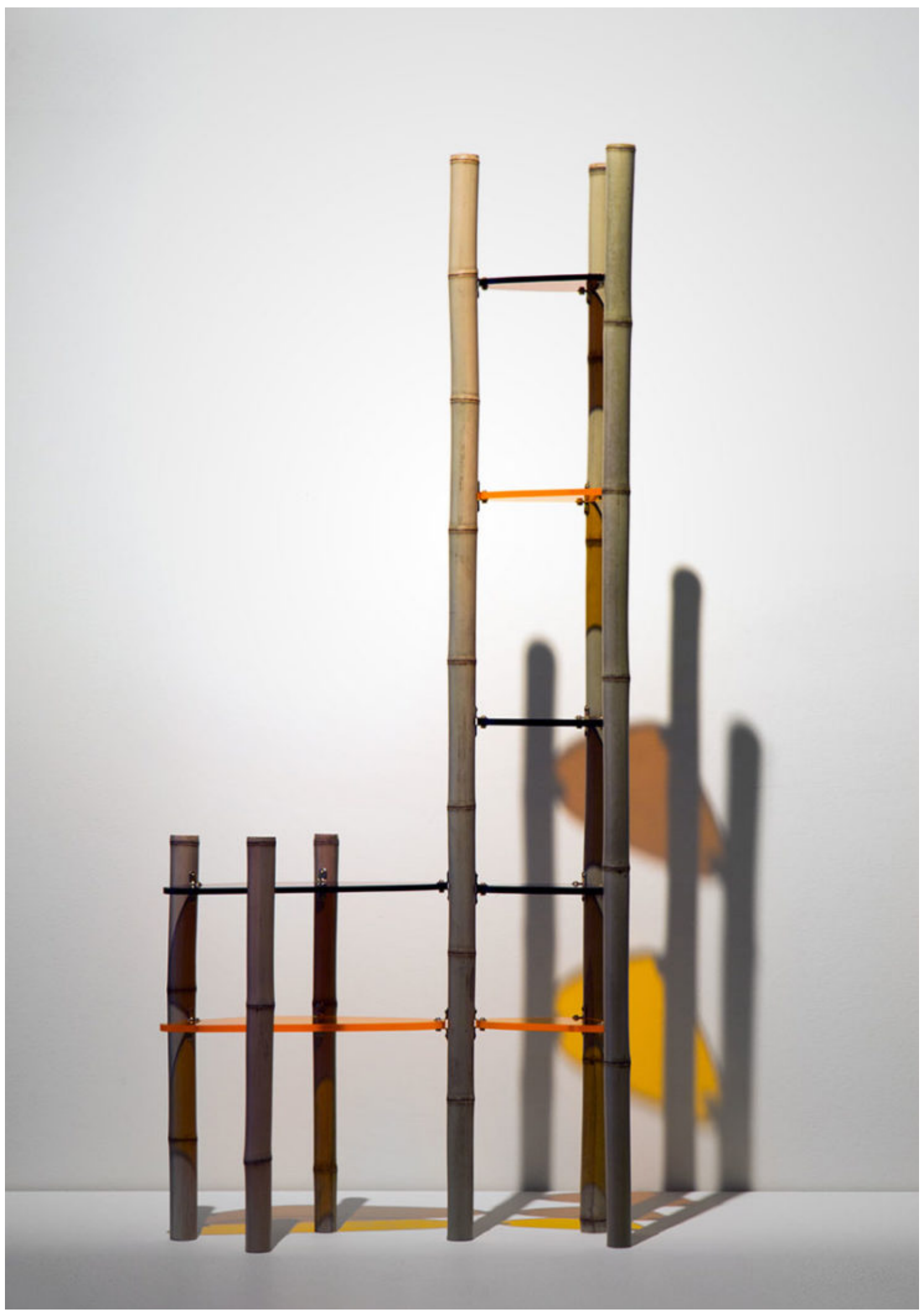

Fig. 5: Brunno Jahara. Palafita, 2014

(C) Studio Brunno Jahara http://www.brunnojahara.com 
is, in reality, a contradiction with respect to its origins. It makes very select and exclusive objects for international firms, far from the pockets and tastes of the majority of its countrymen. This tension between identity and the democratic

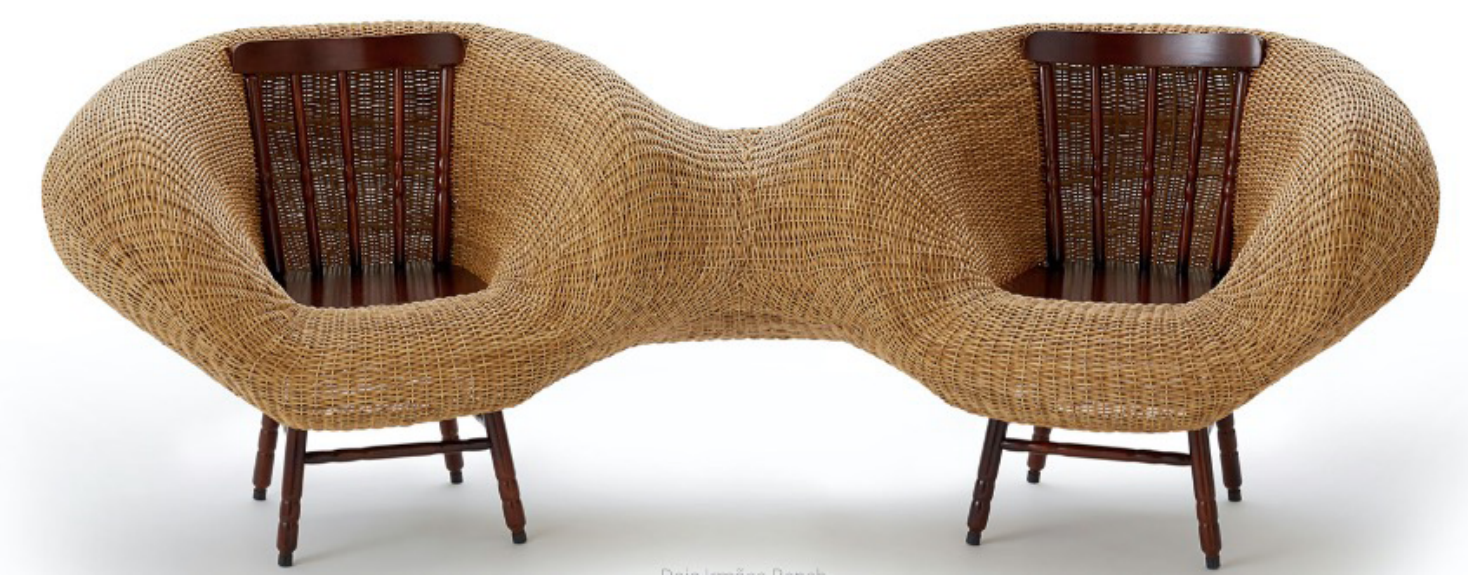

Fig. 6: Fernando and Humberto Campana. Bench Dois Irmãos (Two Brothers). Transwood collection (C) Studio Campana http://campanas.com.br

intentions of some designers as opposed to the obstinate reality of the market and patterns of consumption may also be ascertained in the case of Clara Porset, born in Cuba, but considered as one of the pioneers of modern design in Mexico. She had the great merit of having worked and stood out in a world of men and to have become well-known in the United States for her revisions of Mexican furniture in a number of exhibitions held by MoMA in 1941 (Organic Design for Home Furnishing) and in 1948 (Prize Design for Modern Furniture). Like the architect Luis Barragán, with whom she collaborated on a number of different projects, she was searching for the Mexican character in her designs, integrating the modernity of the international context with unique products rooted in Mexican culture. ${ }^{33}$ She never renounced the promotion of Mexican design and that her products were to reach all consumers, in accordance with her militant left-wing politics. As she expressed in private correspondence, she looked for the Mexicaness in her designs, a pretention that coincides with the nationalistic character of the post-revolutionary period in Mexico and with the official message of the elite that wished to culturally construct a system of antiimperialist, anti-globalized, traditional and indigenous objects, but, at the same 
time, attractive and cosmopolitan. Clara Porset's frustration was to find that her pieces were finally produced by private industry and acquired by the middle and upper classes that lived in new bourgeois neighbourhoods like El Pedregal. Her native aesthetics, her revolutionary nationalism, her ideal of social justice through everyday objects never reached consolidation as she had wanted. ${ }^{34}$ In 1951 she organized the exhibition "El arte en la vida diaria. Exposición de objetos de buen diseño hechos en México" (Art in daily life. An exhibition of well-designed objects made in Mexico), a fusion of popular art and design with an original museography where, both those objects produced in series as well as those that could be found piled up in any craft store, were shown as unique pieces (Fig. 7 and 8). For Porset, that exhibition was a metaphor for the role that industrial design and traditional products could achieve in improving quality of life in people's daily lives, both materially and affectively.

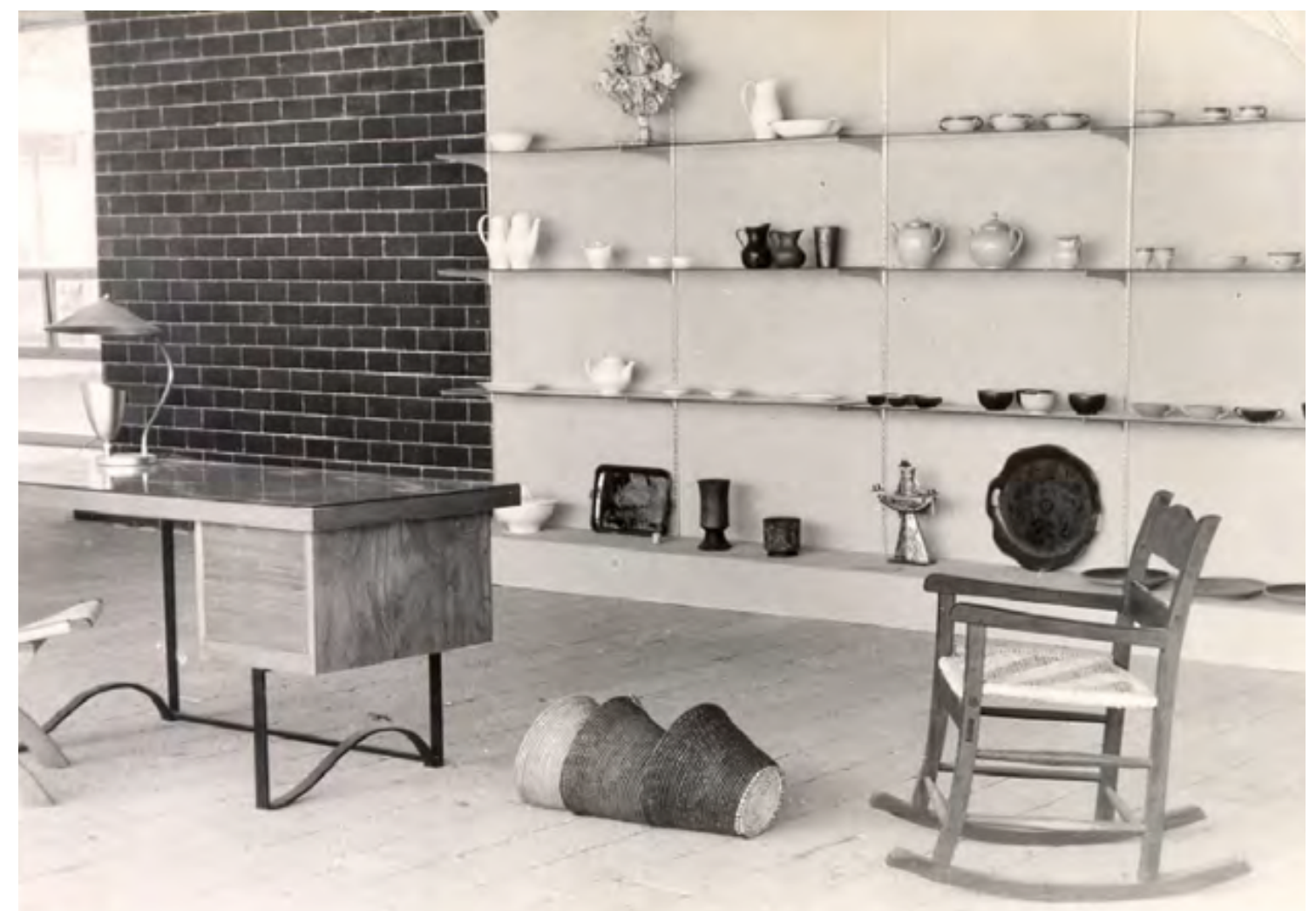

Fig. 7: Display of household goods, basketry and furniture in Arte en la vida diaria. Exposición de objetos de buen diseño hechos en México (Art in Daily Life. Exhibition of Objects of Good Design Made in Mexico) organized by Clara Porset, Ciudad Universitaria, Mexico, 1952. Photography Lola Álvarez Bravo. C Clara Porset Archive, CIDI, UNAM 
The exhibition "Sillas de México" (Chairs from Mexico) (2018) by Óscar Hagerman could be interpreted as an extension of the ideas of Clara Porset. The architect, who had worked with Mexican, rural communities and had researched traditional crafts from the country, created furniture, in this case chairs, that were inspired by the simple, popular model of wood and straw, a low style with elementary ergonomics, with starting assumptions similar to that of Porset: respect of materials and local techniques and the study of the uses of popular chairs. He begins with the Arullo chair in 1969 (Fig.9), taken from rural, wooden stick chairs, a good example of how design could bring together popular references and return once again as a reconverted object to the same rural society and not to elite consumers of exclusive objects. The architect, who was so sensitive to the place and to the interaction of construction with the natural and social environment, conceived furniture "as the smallest of architectures" and the chair as a "space to be" and not merely as a functional object. ${ }^{35}$ Perhaps, because of this, his chairs have been such a success among the public from all social spheres, because they maintain the sentiments of human presence and not only formal values. Half a century later, Hagerman achieved Porset's original dream of social design, that does not manufacture a product for a select few but integrates the everyday nature of the common people since it responds to their cultural necessities.

In the case of Argentina, the dynamic of design has been closely linked to the influence of the modern movement and to rationalism, above all, as from the 1940's, as the wake of Concrete Art influenced the methodology of rational and scientific design of the highest quality but removed from roots. That idiosyncrasy of Argentinian design, which also coincides with Chilean characteristics, has been maintained up to the present, possibly due to the cultural weight of European immigration, or, because of industrial pressure which at certain moments experiences unprecedented production in Latin American countries, so distant from the great centres of international design. 


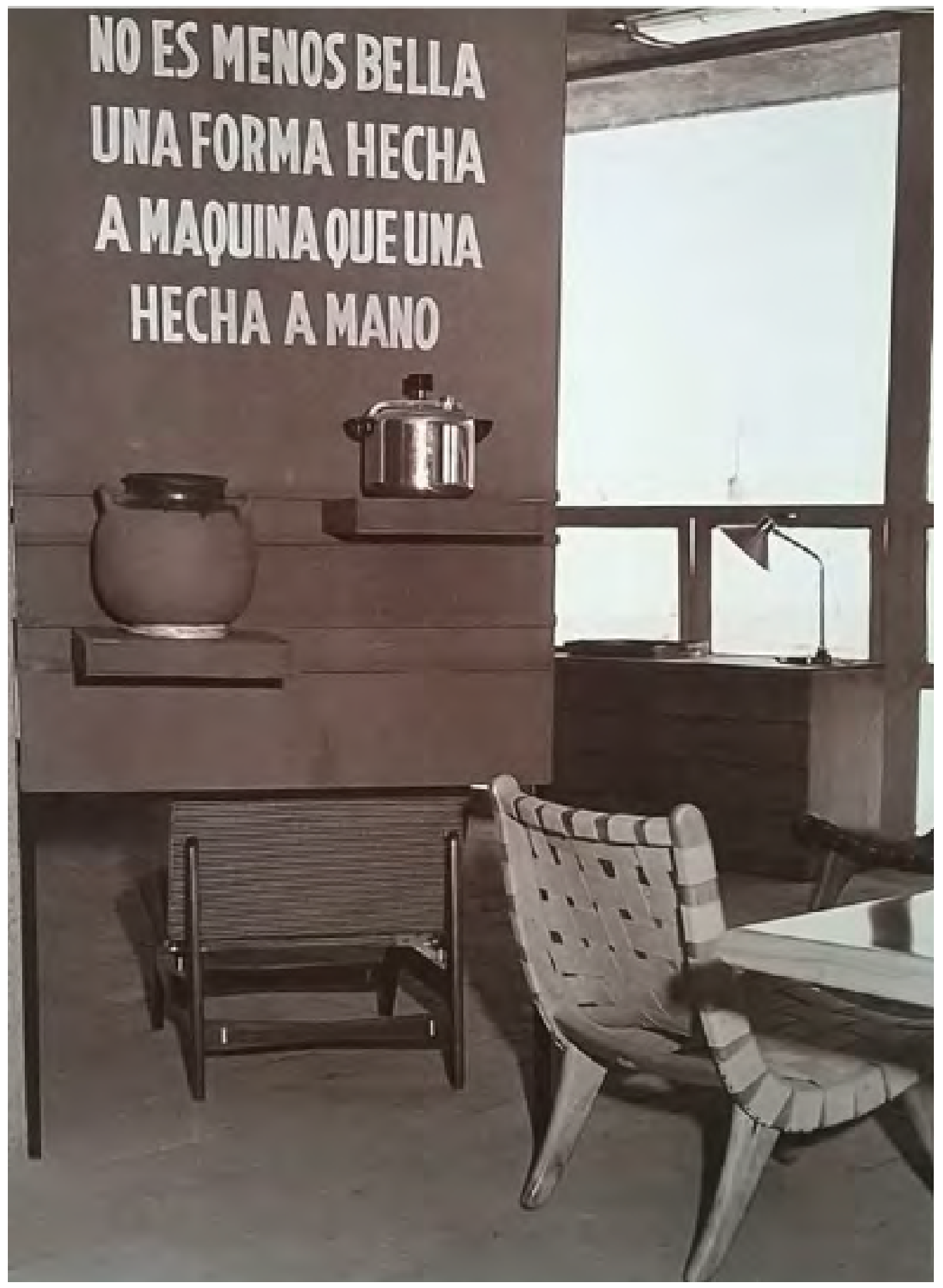

Fig. 8: Display of pots (made of clay andsteel "Ecko") and furniture with the slogan "The machine-made form is no less beautiful than the handmade form' in Art in Daily Life. Exhibition of Objects of Good Design Made in Mexico organized by Clara Porset, Ciudad Universitaria, Mexico, 1952. (C) Clara Porset Archive, CIDI, UNAM 
Some Argentinian designers, such as Eugenio Aguirre, lay claim to a supposed native inspiration, for example, in his series of Escritorios (Desks) (2007-2008), even if the model is not indigenous, but rather, proceeds from European and North American counting house tables from the end of the $19^{\text {th }}$ century and the beginning of the $20^{\text {th }}$ century as a functional piece of furniture for writing and for gathering administrative documents.

\section{Design, heterogeneity and Latin America: some reflections}

Probably due to the immediate inheritance of European rationalism in its early constitution, at first sight it appears complicated to relate the practice of the first Latin American design projects with a decolonial stance, motivated by epistemic disobedience or by aesthesis. However, it is undeniable that Latin American indigenous culture was rescued and incorporated, although in a subtle way, by European producers who arrived in those countries and

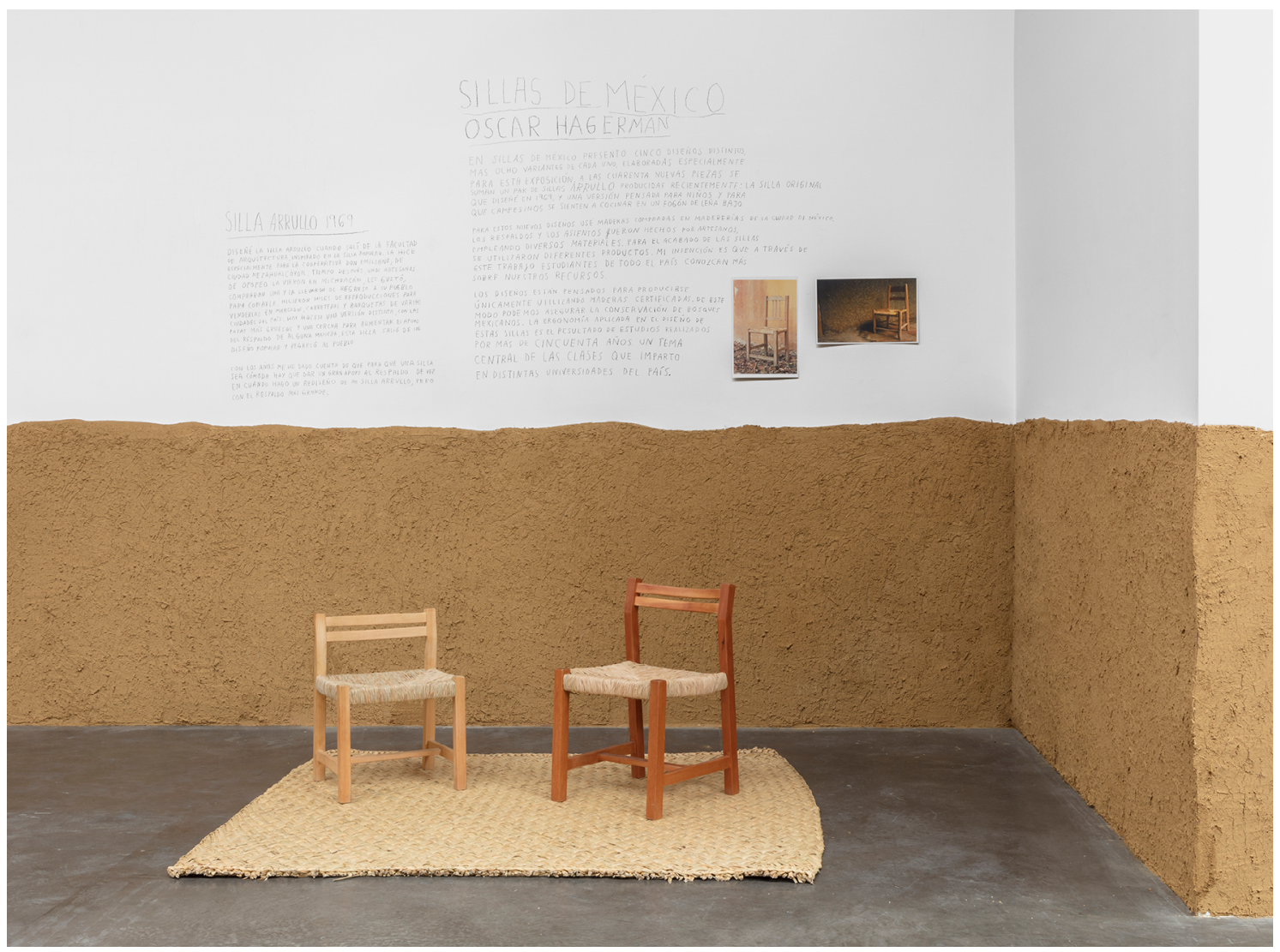

Fig. 9: Óscar Hagerman. Arrullo, 1969. 
decided to pluralise forms through the construction of a dialogue between local knowledge and the universalising proposal of the Modern Movement, as can be seen in the examples of functional works from creators like Lina Bo Bardi and Joaquim Tenreiro.

Later generations of Latin American designers and producers found themselves involved in the paradox of defending and recuperating the vernacular, producing objects (and ideas) that could only be consumed and given a new meaning by a minute sector of the inhabitants of the region. A significant part of this contradiction is due to the very logic of capitalism present in the process of globalisation, which, in order to benefit development and 'modernisation', captures, strips and objectifies the diverse, transforming it into exclusive merchandise ${ }^{36}$ Returning to the thought of García Canclini, not everything that falls under the homogenizing prism of the broad umbrella of globalization can be interpreted as an explicit form of transgression. Certain cultural actions and products, which use the diversity of their own cultural forms as a distinctive element, are not carried out "as a simple resistance in opposition to global movements, but rather, building on their ambivalences and contradictions in order to proliferate with them". ${ }^{37}$

Meanwhile, it must be pointed out that in recent years proposals have emerged in Latin America from creators, collectives and designers in which decolonial postulates, which breach the walls of academic institutions, can clearly be appreciated. Their proposals are supported by the plurality and diversity of cultural and indigenous forms for the construction of effective cultural resistance. They are searching for an understanding of design as a construction tool in a project for a new reality, committed to lasting environmental and social sustainability which improves the lives of Latin American populations. It is more and more frequent to hear the terms social, collaborative or cooperative design, and proposals like those put forward by individual creators: Coco Cerrella, advocate of graphic activism, or Germán Lang and San Spiga, who 
promote design with a Latin American identity. Likewise, collective practices arise like that of the Cooperativa de Diseño (Design Cooperative) where, permeated by gender perspectives and under a collaborative and cooperative vision, seven women designers work together with self-managed organizations and communities of craftswomen to express vernacular forms along with the practice and teachings of more contemporary design.

\section{NOTES}

1 Néstor García Canclini, La globalización imaginada (Buenos Aires: Paidós, 1999), 13.

2 Immanuel Wallerstein, El moderno sistema mundial III. La segunda era de gran expansión de la economía-mundo capitalista, 1730-1850 (Madrid: Siglo XXI Editores, 2010).

3 Francisco Entrena Durán, Modernidad y cambio social (Madrid: Trotta, 2001), 238.

4 Walter Mignolo, Desobediencia Epistémica: Retórica de la Modernidad, Lógica de la Colonialidad y Gramática de la Descolonialidad (Buenos Aires: Ediciones del Signo, 2010), 9.

5 García Canclini, La globalización imaginada; and Anthony Giddens, Un mundo desbocado. El efecto de la globalización en nuestras vidas (Ciudad de México: Santillana Ediciones, 2000).

6 García Canclini, La globalización imaginada, 63.

7 Yasser Farrés Delgado and Alberto Matarán Ruiz, "Hacia una teoría urbana transmoderna y decolonial: una introducción," Polis. Revista Latinoamericana, no. 37 (May 2014), 2-3, https://journals.openedition.org/polis/9891\#quotation (accessed Mai 20, 2020).

8 Giddens, Un mundo desbocado, 20.

9 Giddens, Un mundo desbocado, 21.

10 Giddens, Un mundo desbocado, 22.

11 José Martí, "Nuestra América," Revista Ilustrada, (Jan 1891), http://bibliotecavirtual.clacso.org.ar/ar/libros/osal/osal27/14Marti.pdf (accessed June 2, 2020).

12 José Carlos Mariátegui, Siete ensayos de interpretación de la realidad peruana, $3^{\mathrm{a}}$ ed. (Caracas: Biblioteca Ayacucho, 2007). 
13 Fernando Ortiz, Contrapunteo cubano del tabaco y del azúcar (Madrid: Cátedra, 2002).

14 Césaire founded the magazine L'étudiant noir, together with Léopold Sédar Senghor and Léon-Gontran Damas, where the term negritude first appeared in 1935. See Ernst Wihelm Müller, "L'Etudiant Noir, négritude et racisme. Critique d'une critique." Anthropos, no.91 (1996): 5-18, https://www.jstor.org/stable/40465269?seq=1 (accessed Mai 20, 2020).

15 Frantz Fanon, Los condenados de la tierra (Ciudad de México: Fondo de Cultura Económica, 1963).

16 Néstor García Canclini, Culturas Híbridas: estrategias para entrar y salir de la modernidad (Ciudad de México: Grijalbo, 1989) and Néstor García Canclini, "Noticias recientes sobre la hibridación", TRANS. Revista Transcultural de Música, no.7 (Dec 2003), http://www.sibetrans.com/trans/article/209/noticias-recientes-sobre-la-hibridacion (accessed April 2, 2020).

17 The Grupo Modernidad /Colonialidad (Modernity/Coloniality Group) has been developing its studies since the end of the 20th century. It is made up of intellectuals who work in various Latin American countries and also in universities in the United States (mainly Duke University). In a transdisciplinary way, it has gathered names such as Aníbal Quijano, Catherine Walsh, Walter Mignolo, Enrique Dussel, Nelson Maldonado-Torres, Libia Grueso, and others. See Damián Pachón Soto, "Nueva Perspectiva Filosófica en América Latina: el grupo Modernidad/Colonialidad." Ciencias Políticas, no. 5 (Jan 2008), 8-35, http://www.bdigital.unal.edu.co/20801/1/17029-53780-1-PB. pdf (accessed Mai 20, 2020).

18 Walter Mignolo, La idea de América Latina. La herida colonial y la opción decolonial (Barcelona: Gedisa, 2007) and Mignolo, Desobediencia Epistémica.

19 García Canclini, La globalización imaginada, 10.

20 García Canclini, La globalización imaginada.

21 Mignolo, Desobediencia Epistémica.

22 Mignolo explains that the coloniality of being imposes rules, normally binary and static, that define the subject in terms of gender, sexuality, subjectivity and knowledge. In Mignolo, Desobediencia Epistémica, 9-17.

23 Walter Mignolo, “Aesthesis Decolonial." Calle 14: Revista de Investigación en el campo del arte, no. 4 (Jan 2010), 10-25.

24 Another of the concepts handled by the decolonial theory is the strategy of detachment: "it consists of denaturing the concepts and conceptual fields that make up ONE reality", in Mignolo, Desobediencia Epistémica, 35.

25 Mignolo, Desobediencia Epistémica, 40.

26 Rosalía Torrent and Joan A. Marín, Historia del diseño industrial (Madrid: Cátedra, 2017), 333.

27 Alessandra Alves Paula Rego and Inah Curäo Cunha, "O mobiliário brasileiro e a aquisição de sua identidade." Linguagem Acadêmica, vol. 6, no. 3 (2016), https://claretiano.edu.br/revista/94/linguagem-academica (accessed June 5, 2020).

28 Joana Wanderley, Sebastiana Lana and Luiz Ozanan, "Joaquim Tenreiro: o patrimônio artesanal da madeira no móvel moderno brasileiro," Convergências. Revista de Investigação e Ensino das Artes, vol. 12 (2019).

29 Marize Malta. "Joaquim Tenreiro. Estudio sobre Móvel colonial e experimentos para um móvel moderno no Brasil,” Res Mobilis vol. 5, no 6(II) (2016), 457-58. DOI: 


\section{https://doi.org/10.17811/rm.5.2016.439-461}

30 Cristina García Ortega, "Lina Bo Bardi. Movèis e interiores (1947-1968) interlocuções entre moderno e local" (PhD diss. Sao Paulo University, 2008), 123.

31 García Ortega, "Lina Bo Bardi", 176.

32 Adriana Dornas, "The Concept of Identity and Culture in Three Collections of a Designer - Contemporary Elements," The Design Journal, 22, no.5 (2019), DOI: $10.1080 / 14606925.2019 .1632678$

33 Óscar Salinas Flores, Historia del Diseño Industrial (México: Editorial Trillas, 2003).

34 Randal Sheppard, "Clara Porset in Mid Twentieth-Century Mexico: The Politics of Designing, Producing and Consuming Revolutionary Nationalist Modernity," The Americas 75, no. 2 (2018). doi:10.1017/tam.2017.182

35 Sandra Amelia Martí, “Óscar Hagerman.", Anales Del Instituto De Arte Americano E Investigaciones Estéticas «Mario J. Buschiazzo», 49, no. 2, (2019): 159-170, https:// publicacionescientificas.fadu.uba.ar/index.php/anales/article/view/665 (Accessed 10 June 2020)

36 Suely Rolnik, "Despachos no museu. Sabe-se lá o que vai acontecer...," São Paulo em Perspectiva, 15, no.3, (2001), 3-9, DOI: 10.1590/S0102-88392001000300002, https:// www.scielo.br/scielo.php?script=sci arttext\&pid=S0102-88392001000300002\&l$\underline{\mathrm{ng}}=\mathrm{pt} \& \mathrm{t} \operatorname{lng}=\mathrm{pt}$ (Accessed 10 May 2020)

37 Garcia Canclini, La globalización imaginada, 51.

Received: 2020-06-25

Revised: 2020-07-13

Accepted: 2020-07-13 